\title{
The Effectiveness of Indonesia Supreme Court Regulation Number 1 Year 2016 Concerning Mediation of Marriage Disputes
}

\author{
Sukaenah Sukaenah ${ }^{1 *}$, Rusli Rusli ${ }^{2}$, M. Taufan B ${ }^{3}$ \\ ${ }^{1}$ Islamic Law Department, Postgraduate, Institut Agama Islam Negeri Palu \\ 2 Islamic Law Department, Postgraduate, Institut Agama Islam Negeri Palu \\ ${ }^{3}$ Islamic Law Department, Postgraduate, Institut Agama Islam Negeri Palu
}

This paper discusses the effectiveness of Indonesia Supreme Court Regulation No. 1 year 2016 concerning mediation marital disputes in the Religious Court. This study used qualitative research method. Data was gathered through observation, in-depth interviews, and documenta studies. Data were analyzed through data reduction, presentation, verification, and conclusion drawing. The results of the study shows that effectiveness of PERMA No. 1 of 2016 has been successfully implemented, but the regulation is not effective to reduce divorce rates. This is because the cases that have been reconciled are still few compared to failed mediation. The efforts carried out by the mediator to make mediation effective are merely to act as facilitators by explaining the purpose of mediation to litigants, providing facilities to carry out mediation and increasing the ability of mediators. Supporting factors: Implementation of Mediation based on PERMA Number 1 Year 2016 which is effective, Qualification of Mediators, Facilities, Community Compliance and cultural factors. Inhibiting factors includes technical factors such as mediator limitations, longer mediation time, non-technical factors includes lack of understanding for the parties about the importance of mediation.
\end{abstract}

ARTICLE

INFORMATION 


\section{Introduction}

Mediation is an alternative dispute resolution. It is said so because mediation is a form of dispute resolution outside the court, which is flexible, fast, and inexpensive, and gives access to the conflicting parties to obtain justice or a satisfactory settlement, win-win solution. ${ }^{1}$

It is different if the dispute is resolved through litigation, although the Judge's ruling has been considered so well as to provide the fairest possible justice. However, because each party has different interests, the decision still causes dissatisfaction for the losers. Therefore it is truly wise if every dispute can be resolved through peace. With peace, neither side feels defeated, and more importantly, they are honored.

According to Gary Goodpaster, cited in Usman, mediation is a process of negotiating the solutions to problems where outsiders are in a neutral position to work with the disputing parties to help them get the agreement satisfactorily. Unlike the judges or arbitrators, the mediator does not have the authority to decide the case between the parties. But in this case, the parties deputize the mediator to help them solve the problems between them. The assumption is that third parties will be able to change the strength and social dynamics of conflict relations by influencing the parties' beliefs and

1Iswahjudi Karim, “Got a conflict? Go to mediation!" Bapmi Mediator, Adjudicator, Arbitrator, $\quad 1$ Agusutus 2007. Http://Bapmi.Org/En/Ref Articles11 Php (12 Agustus 2018) behavior, by providing knowledge or information or by using a more effective negotiation process and thereby helping the participants to resolve the issues in question. $^{2}$

The birth the Supreme Court Regulation Number 1 of the Year 2016 regarding Mediation Procedures in the Court is encouraging news because the previous regulation namely the Supreme Court Regulation Number 1 of the Year 2008 and the Supreme Court Regulation number 2 of the Year 2003 still cannot represent the aspirations of citizens because they have not yet regulated clearly the mediation procedures, and also have not been able to deal effectively with the stacking cases, especially at the cassation level, because the background of the Supreme Court Regulation Number 2 of the Year 2003 is originated from the accumulation of cases in the Supreme Court.

The role of judges as a mediator is based on the Supreme Court Regulation No. 2 of the Year 2008, which has been replaced by Supreme Court Regulation Number 1 of the Year 2016 on the Mediation Guidelines in the Court which states in Article 4 that all civil disputes submitted to the Court include a case of the resistance (verzet) to the verdict and the party's resistance (partij verzet) or third parties (derden verzet) to the implementation of decisions that have permanent legal force, must first be sought for settlement through mediation, unless otherwise stipulated

2Rachmadi Usman, Pilihan Penyelesaian Sengketa Di Luar Pengadilan (Bandung: PT Citra aditya Bakti, 2003), 79 
based on this Supreme Court Regulation. $^{3}$

A mediator during the mediation process must be able to create an atmosphere conducive to the creation of a compromise between the two parties to the dispute to obtain mutually beneficial results. ${ }^{4}$ In general, the mediator will conduct an assessment by introducing the mediation procedure and stages, but its role is no more than a neutral driver in the process of interaction between the parties. This generally includes that mediation is a process in which the parties with the help of the mediator set their provisions for each settlement. ${ }^{5}$

The mediation process takes thirty days starting from the stipulation of the order to do mediation. And based on the agreement of the parties, the mediation period can be extended through the request made by the mediator at the request of the disputing parties to the judge that deal with the case.

The materials in mediation are not limited to the basis, argument, or reason for claiming someone's rights and damages through the court (posita) and actions aimed at obtaining the protection of the rights granted by the court to prevent eigenrechting or vigilante (Petitum) claims.

\footnotetext{
3PERMA Nomor 1 Tahun 2016 pasal 4.

${ }^{4}$ Gunawan Widjaya dan Ahmad Yani, Hukum Arbitrase, seri Hukum Bisnis (Jakarta: Raja grafindo Persada, 2000), 34.

${ }^{5}$ Gerry Goopaster, Panduan Negosiasi Dan Mediasi, Trans. Nogar Simajuntak (Jakarta: Elips, 1999), 1.
}

With the agreement of the parties and/or legal counsel, the mediator can present one or more experts, community leaders, religious leaders, and/or traditional leaders. The parties must first reach agreement on the binding or nonbinding power of the explanation and/or judgment of the experts and/or community leaders

\section{Literature Review}

\subsection{The Implementation of Mediation} According to The Supreme Court Regulation Number 1 of the year 2016

The Supreme Court Regulation of the Republic of Indonesia No. 1 of the Year 2016 concerning Mediation Procedures in the Court deals with the mediation guidelines, the nature of mediation, the obligation to attend mediation, the cost and place of mediation, the mediator, and the separation of mediation from the litigation process.

In the mediation guideline in the court, the judge should seek peace through mediation between the two parties, so that if the judge does not order or seek peace with the mediating parties then it has violated the provisions of the legislation governing mediation in the court.

If this happens, then in a subsequent legal remedy with an interlocutory decision the court of the first instance is ordered to carry out a mediation process. ${ }^{6}$ The nature of this

${ }^{6}$ Mahkamah Agung Republik Indonesia. Peraturan Mahkamah Agung Nomor 1 Tahun 2016 
mediation process is closed unless the parties want otherwise so that at the end of the mediation, the mediator's notes must be destroyed, and also the matters revealed in the mediation cannot be used as evidence in the Litigation Process Trial. ${ }^{7}$

Peace seeking through mediation is an obligation and has consequences if not carried out by the judge. If viewed from the perspective of the parties, the parties shall directly attend mediation meetings with or without their legal counsel, unless there are valid reasons such as health conditions which are not possible for them to attend, under one's guardianship, living abroad, or currently carrying out their duties for the country, or doing works that cannot be left behind.

This mediation process takes 30 days since the date of the appointment of the mediator so that within the 30 days, a peace agreement must be formed or the information that the mediation fails or cannot be continued. The place of mediation is a room of mediation in the court or another place outside the court agreed by the parties. However, for the judge that serves as a mediator, it is prohibited to conduct mediation outside the court. 8

Mediators in the Supreme Court Regulation No. 1 of the Year 2016

\footnotetext{
tentang Prosedur Mediasi di Pengadilan. BAB I. Pasal 3 ayat (2), (3) dan (4).

7Peraturan Mahkamah Agung Nomor 1

Tahun 2016 BAB II, Pasal 5 ayat (1) dan BAB VI, Pasal 35 ayat (4).

8PERMA No. 1 Tahun 2016 BAB III.

Pasal 11 ayat (1) dan (2).
}

concerning mediation procedures in the court are judges or other parties who have a certificate of the mediator as a neutral party who help the conflicting parties in the negotiation process to seek various possible dispute resolutions without using a way to force a settlement. ${ }^{9}$ Mediator Certificate is a mandatory requirement that must be possessed by a mediator other than judge by attending the education or training organized by the Supreme Court or the institutions that have been accredited by the Supreme Court itself. ${ }^{10}$ In the case of a limited number of mediators, the chairman of the court may appoint an uncertified judge to carry out the function of the mediator. ${ }^{11}$

The mediators' duties in carrying out their functions include; introducing themselves and giving opportunities to the parties to introduce themselves to each other; explaining the purpose and nature of mediation to the parties, explaining the position and role of the mediator that is neutral and not taking decisions to make the rules of mediation with the parties; explaining to the parties that the mediator can hold meetings with one party without the presence of other parties to arrange a schedule of mediation with the parties to fill out the mediation schedule form; providing an opportunity for the parties

9PERMA No. 1 Tahun 2016 BAB I. Pasal 1 ayat (2)

${ }^{10}$ Rusli, R. (2017). Wahdah Islamiyyah

Palu: on Contemporary Islamic Legal Issues in

The Internet. Hunafa: Jurnal Studia Islamika, 14(2) 11PERMA No. 1 Tahun 2016 BAB III.

Pasal 13 ayat (1) dan (2). 
to submit a case and request the solution; inventorying the cases and scheduling the discussions based on a priority scale; facilitating and encouraging the parties to explore the interests; finding various best solutions and working together in achieving resolution; helping the parties in formulating the agreement of peace; submitting reports of the success or failure of mediation; declaring that either party does not have a good intention and submitting it to the Judge. ${ }^{12}$

Mediators in carrying out their duties have a code of ethics, which is based on 5 basic principles of mediator guidelines, including the following.

a. The principle of neutrality. The mediator is obliged to maintain his impartiality towards the parties. In carrying out its duties, the mediator is prohibited from influencing or directing the parties to produce the clauses that benefit one of the parties or the mediator's personal advantage.

b. The principle of self-determination, that explains that the mediator is obliged to carry out mediation in accordance with the principle of selfdetermination by the parties; that the decisions in the mediation process are the result of the agreement of the parties. The mediator must respect the rights of the parties such as the right to leave the mediation process.

c. The principle of confidentiality, in which the mediator is obliged to maintain the confidentiality of Pasal 14. everything in the form of words, notes and the things that are revealed in the mediation process. The mediator must destroy records in the mediation process, at the end of the mediation process. This makes the mediation process separated from the litigation process.

d. The principle of freedom from conflict of interest, that a mediator is prohibited from getting involved in a conflict of interest in a dispute between the parties; in the case that the mediator is aware of a conflict of interest, then he must resign.

e. The principle of ground rules, that the mediator is obliged to explain to the parties at the first meeting such points as the definition, procedures, stages, process of mediation, the role of the mediator, and all issues related to mediation. ${ }^{13}$

Based on these principles, a person can be said to be a good mediator if he or she carries out mediation according to the principles.

As mentioned above, mediation process is different from litigation process. The difference lies in the fact that if there is one party issued a statement in the mediation process, this cannot be used as evidence in the litigation process. All records from the mediator must be destroyed at the end of the mediation process. Even in the proving process, the mediator cannot be a witness of what he found in the

${ }^{13} \mathrm{http}: / /$ www.hukumonline.com/berita /baca/lt56de6fd38b4ba/hakim-diah-sulastridewi-dan-cerita-tentang-mediasi-, Accessed 8 April 2018. 
mediation process in the trial process. The mediator cannot be sentenced to jail, and responsible for the contents of the agreement in the mediation. ${ }^{14}$

In carrying out a mediation in the court, the stages or procedures of mediation are divided into both premediation and mediation process.

The pre-mediation stage is the stage before the mediation process. This includes an explanation of the obligations of the parties to attend and have good intentions on mediation, the selection of the mediator and the deadline, and the summons of the parties. ${ }^{15}, 16$ Meanwhile, the mediation process is the stage where the mediator starts the mediation process with unlimited scope to posita and lawsuit. This mediation process includes a meeting between the mediator and both parties, a mediator meeting with one party, submission of case resumes, the involvement of experts and community leaders, and the agreements of mediation. However, the following is further explanation regarding the premediation and mediation process stages.

\section{a. Pre-Mediation Stage}

First of all, before mediation is carried out, there must first be a lawsuit

14PERMA No. 1 Tahun 2016 BAB VI. Pasal 35 ayat (3), (4), (5) dan (6).

15 Rusli, R. (2018). Fikih Ekologi dan Kearifan Tradisional: Tinjauan Terhadap Konsep Ihya' al-Mawat dan Hima. Hunafa: Jurnal Studia Islamika, 5(3), 287-298.

16 Rusli, R. (2009). Gagasan Khaled Abu Fadl tentang "Islam Moderat" versus "Islam Puritan" (Perspektif Sosiologi Pengetahuan). Jurnal Ilmiah Ilmu Ushuluddin, 8(1), 99-123. that is registered with the Registrar of the Religious Courts. After that, there was the appointment of a Judge's panel by the Head of the District Court. Afterwards, the chairman of the assembly determines the first day of the hearing, and orders the bailiff or substitute bailiff to summon both parties on the appointed day (Article 121 paragraph (1) HIR, 145 paragraph (1) Rbg). ${ }^{17}$

Based on the provisions in Het Herziene Inlandsch Reglement, article 130 paragraph (1) or Rechtsreglemen voor de Buitengewesten, article 154 paragraph (1) states that Judges are obliged to work for peace between the parties. ${ }^{18}$ Then the stipulations on the settlement of peace are confirmed by the existence of Supreme Court Regulation No. 1 of the Year 2016 on mediation procedures in the court, in article 4, paragraph (1) and (2) which states that all civil disputes submitted to the Court, including a case of resistance (Verzet) or verdict (Verstek) and the resistance of a third party (Derden Verzet) against the implementation of the decision that has permanent legal force, efforts must first be resolved through mediation, except for disputes as follows:

Disputes that have a certain period for settlement; disputes whose examination is carried out without the presence of the plaintiff or defendant

\footnotetext{
17Surat Edaran Mahkamah Agung No.01 Tahun 1974 tertanggal 2 Mei 1974.

18Pasal 130 ayat (1) Het Herziene Inlandsch

Reglement (HIR)/Pasal 154 ayat

Rechtsreglemen voor de Buitengewesten (Rbg). 
who has been properly summoned, counter-claim (Rekonvensi) and the entry of a third party in the case (Intervensi), disputes concerning the prevention, rejection, cancellation and ratification of the marriage; and disputes submitted to the court after seeking out-of-court settlement through mediation with the help of a certified mediator registered at the local court but declared unsuccessful based on the statements signed by the parties and the mediator. ${ }^{19}$

During the first session, the mediation procedure was also explained, such as the definition and benefits of mediation; the obligation of the parties to attend and have good intentions as well in the mediation process, peace agreement follow-up, and signing of Mediation Explanation Form. ${ }^{20}$ In mediation, the parties can be represented by a the representative based on special power of attorney; however, if the mediator wants to conduct a caucus, the parties must deal with the case directly and may not be represented, which caucus is a mediator meeting with one party without the presence of other parties. ${ }^{21}$ After speaking about the obligations of the parties to carry out mediation, the parties have the right to choose the mediator.

The mediator chosen by the parties must be recorded in the List of

4 ayat (1).

19PERMA No. 1 Tahun 2016 BAB I. Pasal

20PERMA No. 1 Tahun 2016 BAB IV.

Pasal 17.

21PERMA No. 1 Tahun 2016 BAB III.

Pasal 14 huruf e.
Mediators at the local court. Mediators can be more than one person, in which the division of tasks is determined by agreement between mediators. If the parties prefer the mediator outside the court, the costs incurred for that will be borne by the parties based on the agreement. If within two days the parties have not been able to determine the mediator, the case examining judge will choose a judge as a mediator or a court employee who is certified or with the appointment of the Chair of the Religious Court. After selecting the mediator, the panel of judges examining the case issues the order of mediation and appoints the mediator concerned. With this determination the trial process is postponed, and awaits the mediation process. $^{22}$

After the appointment of the mediator, the mediator determines the day and date of the mediation meeting. The summoning of the parties is carried out by the bailiff based on the Judge's order legally without the need for a power of attorney. In relation to the summoning of mediation costs, it is charged to the plaintiff through a case fee down-payment. In carrying out the summons, as mentioned above, it can be done without a special power of attorney, so that without the instrument from the judge examining the case, the bailiff is required to carry out the order of the judge mediator and the non-judge

22 PERMA No. 1 Tahun 2016 BAB IV. Pasal 19. 
mediator to make summons to the parties. $^{23}$

\section{b. Mediation Process}

The mediation process is the stage where the mediator starts mediation with the scope not limited to posita and petitum claim. Mediation is confidential, so the judge mediator or mediator must immediately destroy the mediation documents after the completion of the mediation. The mediation time limit is 30 days from the stipulation of the mediation order; however, the mediation can be extended for 30 days based on the agreement of the parties, and the extension must be requested from the judge of the case review.

The stages of the mediation process are informal in the sense that they are not sequentially regulated in the Supreme Court Regulation of the Republic of Indonesia, No. 1 of the Year 2016, but there are several stages that are usually taken. At the first mediation meeting, the parties are explained again related to the provisions of mediation, and the mediation rules are also agreed by the parties, which include subsequent mediation meetings or preparation of mediation meeting schedules. The agreement between the parties and the mediator is not regulated sequentially in the Supreme Court Regulation No. 1 of the Year 2016, but there are some things that are regulated in the regulation, among others:

23 PERMA No. 1 Tahun 2016 BAB IV. Pasal 21 ayat (2) dan (3).
It is stipulated in Article 24, the Supreme Court Regulation of the Republic of Indonesia, No. 1 of the Year 2016, that no more than five days after the determination of the mediator, the parties can submit a case resume to the mediator and other parties. This resume contains the case and effort of settlement. In response to the case resume submitted by the parties, the mediator tried to find a way of meeting the desires of the parties. Submitting the case resume is intended to make the parties and mediators understand the dispute to be mediated, and this will in turn help smooth the mediation process. ${ }^{24}$

This meeting is known as kaukus, which means mediators of meetings with one party without the other party. The reason of this kaukus is that the mediator can listen to the opinion of one of the parties without any force, helps the parties to channel their emotions without hampering the progress of mediation, and enable the mediator to search for additional information especially that relates to dispute resolutions. ${ }^{25}$ However, this kaukus must be informed to the other parties that a mediator with one of the parties is carrying out a kaukus. This kaukus must be based on the principles of mediators, namely neutrality, self-determination of the parties, confidentiality, free from conflicts of interest, and based on the provisions of the mediation in force.

\footnotetext{
${ }^{24}$ Rahmadi, Mediasi: Penyelesaian, 35.

${ }^{25}$ Rio Satria, Pelaksanaan Mediasi di Pengadilan, Diakses 8 April 2018
} 
Article 26 of the Supreme Court Regulation No. 1 of the year 2016, mediation can involve experts and community leaders on the basis of the agreement of the parties. The expert referred to in this regulation is not explained in detail, so it can be analogized that the provisions relating to this expert are based on judicial provisions in general, namely people who have education or experience over a long period of time in pursuing a particular profession. ${ }^{26}$ Community leaders in question include community leaders, religious leaders or traditional leaders. The binding power of the opinions of the experts and community leaders is in accordance with the agreement of the parties. Related to the costs arising from the use of experts, it is charged based on the agreement of the parties.

After knowing clearly the case and the proposal of peace desired by the parties, conducting a kaukus with the parties, hearing the statements of experts or community leaders if needed, the mediator can identify the conflicts and interests of the parties; based on these findings, the mediator searches for a meeting-point or agreement between the parties where no one party is won but the parties are equally won, then the Mediator can propose various options of problem solving options to the parties.

26D. Y. Witanto, Hukum Acara Mediasi dalam Perkara Perdata di Lingkungan Peradilan Umum dan Agama menurut PERMA 1 Tahun 2008 tentang Prosedur Mediasi di Pengadilan (Bandung: Alfabeta, 2011), 199.
According to Witanto, after the stage of kaukus and expert information if needed, negotiations took place between the parties mediated by the mediator. This negotiation aims to formulate or seek agreement on dispute resolution, which will later be formulated into a peace agreement. Negotiation basically runs throughout the mediation stage, from the first meeting to the kaukus which is actually a negotiation mediated by the mediator. ${ }^{27}$

After submitting a proposed solution to the problem, several possible agreements can occur, including the parties agree to peace; the parties agree to make peace for some parties or peace; nor can the parties find a meeting point for a peace agreement.

If the parties reach an agreement in mediation, according to the provisions of Article 27 of the Supreme Court Regulation No. 1 of the Year 2016, the parties with the assistance of a mediator are required to formulate a written agreement of peace signed by the parties and the mediator. A peace agreement is a document that contains terms agreed upon by the parties to end a dispute, which is the result of a peace effort with the help of a mediator. ${ }^{28}$

The agreement must not be contrary to law, public order, and morality; detrimental to third parties, or cannot be implemented. According to Witanto, the mediator in helping to formulate a peace agreement is basically passive, because the peace agreement must be basically drawn up by the

27Ibid.

28PERMA No. 1 Tahun 2016 pasal 27. 
parties, and the existence of the mediator is only to facilitate the mediation to be carried out properly. ${ }^{29}$

The peace agreement can be submitted to the judge examining the case in order to be strengthened into a deed of peace. Case examining judges within two days must study and examine the agreement immediately. After that, if it meets the provisions referred to in Article 27, then within a maximum period of three days, the judge who examines the case issues the day in which the recitation of the deed of peace is held. ${ }^{30}$ A peace deed is a deed that contains the contents of a peace agreement and the judge's decision to strengthen the peace agreement which is not subject to ordinary or extraordinary legal efforts. The existence of this peace deed is a reinforcement of the peace agreement between the parties, in which this peace deed has an executorial power like a court decision. ${ }^{31}$

Partial Peace is achieved in the case if an agreement occurs between the plaintiff and a part of the defendant, in which the plaintiff changes the lawsuit by no longer submitting it to the defendant who has reached a partial peace agreement. As is the case with the peace agreement, the plaintiffs and the defendants make peace agreement, which will then be strengthened by a peace certificate. Then in the case that the parties reach an agreement on a part of all disputed objects or claims, then an

29Witanto, Hukum, 201.

30PERMA No. 1 Tahun 2016 BAB V. Pasal 28.

31PERMA No. 1 Tahun 2016 pasal 27. agreement on a part of the disputed object is made a peace agreement, which will then be strengthened with a peace deed. So in that case, in a follow-up trial, the judge examining the case will only examine the object of the dispute that has not been successfully agreed upon by the parties. ${ }^{32}$

If the parties cannot reach an agreement in mediation after reaching a 30 day-deadline or with an extension, because there is one party who is not in good intention in conducting the mediation, the mediator shall declare the mediation to fail and notify the Judge who examines the case. The mediator is obliged to state that mediation cannot be carried out, and gives a written notice to the judge who examines the case in the cases of, among others, involving assets or interests that are clearly owned by another party, but not included in the lawsuit involving the authority of the institution or agency which is not a litigant party. After this, the caseinvestigating judge can immediately issue a stipulation to proceed with the hearing of the case according to the applicable procedural law. ${ }^{33}$ This is in line with the opinion of Fei Lanfang who stated that:

Judge-mediators must always construe the law strictly as written or advance rules out of general legal principles. This task may be easy when a statute is straightforward and clear, but is

32PERMA No. 1 Tahun 2016 BAB V. Pasal 29 dan 30.

33PERMA No. 1 Tahun 2016 BAB V. Pasal 32 ayat (1), (2) dan (3). 
difficult when a statute is unclear or contains omissions. ${ }^{34}$

The mediation in the court is required for every case submitted to the court of first instance except for disputes that are included in article 4 paragraph (2) of The Supreme Court Regulation Number 1 of the Year 2016, in which the mediation procedure is divided into; Pre-mediation is the stage before the mediation is carried out, including an explanation of the obligations of the parties to attend and have good intentions in the mediation, the selection of the mediator and the deadline, and the summons of the parties; and the mediation process, namely the stage at which the mediator begins the mediation process with a scope that is not limited to posita and petitum claim, this mediation process includes the mediator meetings with both parties, or with one party (kaukus), submission of case summary, involvement of experts and community leaders to mediation agreements.

\section{c. Good Intention in Mediation}

The Supreme Court Regulation No. 1 of the Year 2016, article 7, regulates the obligation to carry out mediation in good intention. The parties involved in the mediation process must

${ }^{34}$ Fei Lanfang, "The Role Of The Law In Chinese Judicial Mediation: A Case Study", SelfDetermination, Coercion, Court Mediation, Role Of The Law, Vol. 4 No. 26 (19 September 2014), 392. https://eresources. perpusnas. go.id :2057/ results/DD4773391A5B45A5PQ/1?accountid=25 704, (Diakses 12 Agustus 2018). have good intentions so that with good intentions the mediation process can be carried out and run well. Indicators stating that the parties have no good intention in carrying out mediation are the following:

a. Not present in the mediation process despite being called up twice in a row.

b. Attending the first mediation meeting, but later not attending, despite being summoned twice in a row.

c. Not present repeatedly that leads to disrupting the schedule of mediation.

d. Not submitting or not responding to the case resumes.

e. Not signing a peace agreement. ${ }^{35}$

The implementation of mediation in the presence of the parties who are not in good intention, has a legal impact on the proceedings. In this case, it can be seen from the aspects of the parties who are not in good intention.

\section{Methodology}

This study used a qualitative approach with the object of research is the Religious Court of Palu. The author chose the location of the research based on the consideration that the Religious Court of Palu is a religious court which is always trying to improve the quality of its performance, especially in dealing with various legal cases. In addition, the efforts made are always to create an atmosphere that supports the professionalism and neutrality of the judges as the spearhead in handling various legal cases.

35Perma No 1 tahun 2016 Pasal 7. 
Data were collected using observation techniques, in-depth interviews with officials in the Religious Court of Palu. While the data analysis is done using reduction and verification techniques with various data sources. 36,37 . The reduced data is then analyzed by claiming to the theoretical concepts used in this study. ${ }^{38}$

\section{Result and Discussion}

\subsection{The Effectiveness of the Supreme Court} Regulation of the Republic of Indonesia Number 1 of the Year 2016 in the Settlement of Marriage Conflict

Marriage is an inner and outer bond between a man and woman, which is expected to create a sense of serenity (sakinah) and mercy (mawaddah). To achieve this, it is necessary to have mutual understanding of the interests of both parties, especially those related to rights and obligations. In domestic life, we often encounter people (husband and wife) complaining to others or to their

36 Nurdin, N. (2017a). Research in Online Space: The Use of Social Media for Research Setting Jurnal Sistem Informasi (Journal of Information System), 13(1), 67-77.

37 Nurdin, N. (2017b). To Research Online or Not to Research Online: Using Internet-Based Research in Islamic Studies Context. Indonesian Journal of Islam and Muslim Societies, 7(1), 31-54.

38 Nurdin, N. (2016). The Roles of Information Technology in Islamic Bank Knowledge Management: A study of Two Syariah Banks in Palu. Hunafa: Jurnal Studia Islamika, 13(2),

181-217. https://doi.org/https://doi.org/10.24239/jsi.v1 3i2.444.181-217 families, due to the rights that are not fullfiled, and the obligations that are not carried out the obligations from one party, or for other reasons, which can result in a dispute between the two (husband and wife). And it is not impossible that the dispute will result in the breaking of the marriage ties (divorce), and the joint-property claim cannot be avoided.

Mediation is not something that is easy to define. This is related to the mediation dimension which is very plural and unlimited. Mediation does not provide a model that can be described in detail and distinguished from other decision-making processes. In essence, the mediator must be able to be oriented to the uniformity of actions and mindset of each party to the dispute, so that it is expected to create wider consideration in addressing disputes submitted in a formal way. So, the mediator should remain neutral, always build good relations, speak the language of the parties, listen actively, emphasize potential benefits, minimize differences, and emphasize equality.

Based on the interview, in doing mediation, a judge must be guided by the Supreme Court Regulation of the Republic of Indonesia Number 1 of the Year 2016 and the applicable rules. This is revealed by Mr. Mal Domu, one of the Judges of the Religious Court of Palu Class 1 A that

In conducting mediation, a judge does follow the rules of the Supreme Court and the guideline of mediator behavior. While doing mediation, a judge first introduces 
himself and gives an explanation of mediation, and then the parties are asked to introduce themselves briefly. A judge reads the case resume or lawsuit letter to find out the subject matter. Then, the mediator asks about what the parties want, and what the purpose of the case disputed. ${ }^{39}$

Based on the interview above, Mal Domu as a Judge of the Palu Religious Court Class 1 A argued that the main problem of mediation is the reluctance of both parties who sometimes do not want to be reconciled. The lawsuit starts from disharmony between husband and wife which causes various kinds of problems in the household. One of them is offense. According to Mr. Mal Domu,

No matter how good the mediation will not lead to harmony between two parties who have litigated, especially if they have the intention to divorce and sue each other. The parties have usually insisted to separate, so the desire to make peace is very difficult. Our effort is to provide an insight to both parties through religious knowledge, social science and others in order to get back together and resolve the problem properly. ${ }^{40}$

The purpose of mediation is to resolve disputes between the parties by involving neutral and impartial third

\footnotetext{
${ }^{39}$ Mal Domu, Hakim, PA. Palu Kelas 1 A, "Wawancara", 8 Agustus tanggal, 2018.

${ }^{40} \mathrm{Mal}$ Domu, Hakim, PA. Palu Kelas 1 A, "Wawancara", tanggal, 8 Agustus 2018.
}

parties. Mediation can lead the parties to the realization of a permanent and sustainable peace agreement, given that dispute resolution through mediation places both parties in the same position, neither party is won nor the party defeated.

Dispute resolution is indeed difficult, but that does not mean it is not possible to be realized in reality. The main capital for resolving disputes is the desire and good will of the parties in ending their dispute. This good will sometimes requires the assistance of a third party in its realization. Mediation can provide a number of advantages.

\subsection{The Effectiveness of Mediation Represented by an Attorney}

In the case of the parties unable to attend due to valid reasons as referred to in article 6 paragraph (4), the attorneys can represent the parties to carry out mediation by showing the special power of attorney containing the power of attorney to make decisions. The attorney acts on behalf of the parties. As referred to in paragraph (3), they shall participate in the mediation process in good intention and in a manner that is not contrary to other parties or their attorneys. ${ }^{41}$

Based on the interview with Asri saying that:

The attorney tends to continue the case in litigation so that he gets a lot of fees from his clients. The attorney usually receives the fee

${ }^{41}$ Kunti Nur Aini, Hakim, PA. Palu Kelas I A, "Wawancara", tanggal, 3 September 2018. 
based on working hours or frequent visits to the court. If the case is quickly resolved, the fee obtained is not much, even though in some cases, many parties want to do peace during mediation, but they are influenced by their attorneys in order to continue the case litigation. However, not all attorneys are against mediation, professional attorneys will continuously support peace. ${ }^{42}$

Furthermore, depth interview was carried out to the defendant who argued that:

The information that the parties get from the mediation process through legal counsel is no longer intact, due to the time span of the information received by the attorney by submitting information to the authorizer. ${ }^{43}$

Depth interview was also carried out to a former attorney of the defendant who argued that:

This profession has an important influence in resolving a dispute because the attorney puts forward the interests of the client rather than individual interests. Besides the attorney must explain to the client about the advantages and disadvantages or influence them to choose peace. However, the mediator is less capable in

42Asri, Hakim, PA. Palu Kelas I A, "Wawancara", tanggal, 3 September 2018.

${ }^{43}$ Amiruddin, Pihak yang pernah berperkara, "Wawancara", tanggal, 3 September 2018. conducting mediation because mediation is considered a formality of the procedural law applicable to the court, so that mediation is not carried out as fully as possible. ${ }^{44}$

Based on the above interview, it can be said that in principle the parties may represent the mediation process to the attorney, if the parties are indeed unable to attend or cannot participate in the mediation process in the Religious Court due to illness or being abroad. And the most difficult of dealing with mediation is when the parties represent the mediation process to the attorney who does not understand all the problems experienced by the parties unless the parties have informed them well, and also there is a tendency of the attorney not to want his client to make peace. This is because attorneys' income is from court proceedings. The higher the trial rate, the higher the income, depends on the client's agreement and trust. In addition, the role of the attorneys is very limited in the mediation process, because the ones who get more roles are the parties to the dispute and the mediator, but not all the attorneys are contrary to the mediation process.

\section{Conclusion}

In general, it can be said that the the Supreme Court Regulation No. 1 of the Year 2016 have been implemented in a good way, but they have not been

${ }^{44}$ Arif Sulaeman, Advokad (Kuasa Hukum), "Wawancara", tanggal, 3 September 2018. 
effective in suppressing divorce rates. This is because there are still few cases, aside from mediations that have failed. The efforts made by the mediator are only limited as a facilitator, which is to help resolve disputes to reach an agreement that benefits both parties in a dispute so as to achieve satisfactory results.

\section{REFERENCES}

A, Hasanuddin. Pengantar Ilmu Hukum. Jakarta: Pustaka al-Husna Baru, 2004.

Abbas, Syahrial. Mediasi dalam Perspektif Hukum Syariah, Hukum Adat, dan Hukum Nasional. Jakarta: Kencana, 2009.

Abdurrahman. Kompilasi Hukum Islam Di Indonesi. Jakarta: Akademika, 1992.

Adinanta, Rido Marta. Mediasi dalah hukum Acara Perdata, http://adinata-

putra.blogspot.com/2012/03/mediasidalam-hukum-acara-perdata.html., Diakses 8 Maret 2018.

Ahmadi, Moh. Integrasi Keilmuan: Paradigma Pendidikan Islam Integratif Holistik. Bandung, Batic Press: 2011. Alexander. International and Comparative Mediation: Legal Perspectives, dalam Fatahillah A. Syukur. Mediasi Yudisial Di Indonesia. Bandung: Mandar Maju, 2012.

Ali, Zainuddin. Metode Peneltian Hukum. Jakarta: sinar Grafika, 2009

Al-Khyust, Muhammad Ustman. Membangun Harmonisme Keluarga. Jakarta: Bisthi, 2007.
Almaraghiy, Ahmad Musthofa. Tafsir al maraghiy (Jilid 5),Terjemahan.

Anshori Umar. Semarang: Toha Putra , 1988.

Anggora, M. Toha. Dkk. Metode Penelitian. Jakarta: Universitas Terbuka, 2007

Ashhiddieqy, Teungku Muhammad Hasby. Al Bayan, Tafsir Penjelas AlQur'anul Karim. Semarang: PT. Pustaka Rizki Putra, 2002.

Beck, Connie J. A. Dkk. "Mediator Assessment, Documentation, and Disposition of Child Custody Cases Involving Intimate Partner Abuse: A Naturalistic Evaluation of One County's Practices". Intimate partner violence Divorce mediation Child custody Parenting time Court-connected mediation, Vol. 34: No. 227-240 (2 May 2009), 5. https: $1 / \mathrm{e}-$ resources. perpusnas. go. id: 2057/ results/

DCF024A10F57462DPQ/1?

accountid=25704. $\quad$ (Diakses 12 Agustus 2018)

Dahlan, Aziz Dkk. Ensiklopedi Hukum Islam. Jakarta: PT Ichtiar Baru van Hoeve, 1996.

Darmawan, Ahmad: "Metode Penelitian" http://www sarjanaku com/2011/03/ metode-penelitian.html, Diakses 12 Agutus 2018

Departemen Pendidikan dan Kebudayaan RI. Kamus Besar Bahasa Indonesia. Jakarta: Pusat Bahasa, 2003.

Direktorat jendral Pembinaan

Kelembagaan Agama

Islam. Himpunan Peraturan 
Perundang-undangan Badan Peradilan Agama. Jakarta: Departemen agama RI, 1991.

Duursma, Allard. "A current literature review of international mediation, A current literature review". International mediation, Mediation occurrence, Mediation outcomes, Mediation strategy, Mediator type, Vol. 1 N0. 25. (Tanpa tanggal terbit), 87. The current issue and full text archive of this journal is available at www.emeraldinsight.com/104 4-4068.html. (Diakses 12 Agustus 2018)

Fauzan, Pokok-Pokok Hukum Acara Perdata Di Peradilan Agama Dan Mahkamah Syariah Diseluruh Indonesia. Jakarta: Kencana Prenada media Grup, 2005

Goopaster, Gerry. Panduan Negosiasi Dan Mediasi, Terj. Nogar Simajuntak. Jakarta: Elips, 1999.

Harahap, M. Yahya. Hukum Acara Perdata Tentang: Gugatan, Persidangan, Penyitaan, Pembuktian Dan Putusan Pengadilan. Jakarta: Sianr Grafika, 2005

Harahap, Yahya. Hukum Acara Perdata. Jakarta: Sinar Grafika, 2005.

Harahap, Yahya. Kedudukan Kewenangan dan Acara Peradilan Agama UU No 7 Tahun 1989. Jakarta : Sinar Grafika, 2003.

Hertina. Sosiologi keluarga. Pekanbaru: Alaf Riau, 2009.

John Michael Hoynes, Cretchen L. Haynes dan Larry Sun Fang, Mediation: Positive Conflict Management, Terj. Syahrial Abbas.
Jakarta: Kencana Prenada Media Group, 2011.

Karim, Iswahjudi. "Got a conflict? Go to mediation!" Bapmi Mediator, Adjudicator, Arbitrator, 1 Agusutus 2007. Http://Bapmi.Org/En/Ref Articles11 Php (12 Agustus 2018)

Kementerian Agama RI. Al-qur'an dan Terjemahnya Edisi Transliterasi. Solo: Tiga Serangkai, 2013.

Komariah. Hukum Perdata. Malang: UPT Penerbitan Universitas Muhammadiyah Malang, 2002.

Lanfang, Fei. "The Role Of The Law In Chinese Judicial Mediation: A Case Study", Self-Determination, Coercion, Court Mediation, Role Of The Law, Vol. 4 No. 26 (19 September 2014), 392. https:/ / eresources. perpusnas. go.id :2057/ results/ DD4773391 A5B45A5PQ/ 1 ?accountid $=25704$, (Diakses 12 Agustus 2018)

Mahkamah Agung Republik Indonesia. Himpunan SEMA dan PERMA Tahun 2000 - 2014. Jakarta: MARI, 2014.

Manan, Abdul. Penerapan Hukum Acara Perdata di Lingkungan Peradilan Agama. Jakarta: Kencana Prenada Media Grup, 2006

Margono, S. Metode Penelitian Pendidikan. Jakarta: Rineka Cipta, 2000.

Nasution, S. Metode Research (Penelitian Ilmiah), Usul Tesis, Desain Penelitian, Hipotesis, Validitas, Sampling, Populasi, Obeservasi, Wawancara, Angket. Jakarta: Bumi Aksara, 2011.

Noor, Juliansyah. Metodologi Penelitian: Skripsi, Tesis, Disertasi, dan Karya ilmiah. Jakarta: Kencana, 2014. 
Novita, Ria Ayu. Dkk. Efektifitas Pelaksanaan Undang-undang No. 2 Tahun 1960 tentang perjanjian Bagi hasil tanah pertanian (tanah kering) di desa Bringin

Kecamatan bayan Kabupaten Purworejo, Effectifuity, Sharing Agreemen, Vol. 6 no. 2 (2017), 4. http://www.ejournals1.undip.ac.id/index.php/dlr, (Diakses 15 Agustus 2018)

Nurdin, N. (2016). The Roles of Information Technology in Islamic Bank Knowledge Management: A study of Two Syariah Banks in Palu. Hunafa: Jurnal Studia Islamika, 13(2), 181-217. https://doi.org/https://doi.org/1 0.24239/jsi.v13i2.444.181-217

Nurdin, N. (2017a). Research in Online Space: The Use of Social Media for Research Setting Jurnal Sistem Informasi (Journal of Information System), 13(1), 67-77.

Nurdin, N. (2017b). To Research Online or Not to Research Online: Using Internet-Based Research in Islamic Studies Context. Indonesian Journal of Islam and Muslim Societies, 7(1), 31-54.

Rahmadi, Takdir. Mediasi:Penyelesaian Sengketa Melalui Pendekatan Mufakat. Jakarta: PT.Raja Grafindo Persada, 2010.

Ranuhandoko, I.P.M. Terminologi Hukum Inggris-Indonesia. Jakarta: Sinar Grafika, 1996

Rusli, R. (2009). Gagasan Khaled Abu Fadl tentang "Islam Moderat" versus "Islam Puritan" (Perspektif
Sosiologi Pengetahuan). Jurnal Ilmiah Ilmu Ushuluddin, 8(1), 99-123. Rusli, R. (2017). Wahdah Islamiyyah Palu: on Contemporary Islamic Legal Issues in The Internet. Hunafa: Jurnal Studia Islamika, 14(2)

Rusli, R. (2018). Fikih Ekologi dan Kearifan Tradisional: Tinjauan Terhadap Konsep Ihya' al-Mawat dan Hima. Hunafa: Jurnal Studia Islamika, 5(3), 287-298.

Sarwono. Hukum Acara Perdata Teori Dan Praktek. Jakarta: sinar Grafika, 2011

Soedarsono, Sidik. Masalah Administratif dalam Perkawinan Umat Islam Indonesia. Jakarta : Fa. Dara, 1964.

Soekanto, Soerjono. Pokok-pokok Sosiologi Hukum Edisi Baru . Jakarta: Raja Grafindo Persada, 1988

Soemartono, Gatot. Arbitrase dan Mediasi di Indonesia . Jakarta: PT Gramedia Pustaka Utama, 2006.

Subekti. Pokok-Pokok Hukum Perdata. Jakarta : PT Intermasa, 1989.

Sugiyono. Memahami Penelitian Kualitatif . Bandung: Alfabeta, 2014.

Syakuro, Abdan. Langkah Dalam Menyusun Kerangka Pikir http://www om/2015/03/l html, Diakses, 8 Maret 2018.

Umam, Khotibul. Penyelesaian Sengketa di luar Pengadilan. Yogyakarta: Pustaka Yustisia, 2010.

Undang-Undang Republik Indonesia Nomor 4 Tahun 2004 tentang Kekuasaan Kehakiman

Undang-undang Republik Indonesia No. 7 Tahun 1989 tentang Peradilan. 
International Journal of Contemporary Islamic Law and Society

Vol. 2 No. 1 Tahun 2020

Undang-Undang Republik Indonesia Nomor 1 Tahun 1974 tentang Perkawinan

Usman, Rachmadi. Pilihan Penyelesaian Sengketa Di Luar Pengadilan. Bandung: PT Citra Aditya Bakti, 2003

Widjaya, Gunawan dan Yani, Ahmad. Hukum Arbitrase, seri Hukum Bisnis. Jakarta: Raja grafindo Persada, 2000.

Wirawan. Konflik dan Manajemen Konflik. Jakarta: Salemba Humanika, 2013.

Welikala, Sepalika. "Community Mediation as a Hybrid Practice: The Case of Mediation Boards in Sri Lanka." Community Mediation, Sri Lanka, Legal Pluralism, Alternative Dispute Resolution, Popular Justice. Vol. 3 No. 399-422, (7 July 2016), 404. https://eresources perpusnas. go. id: 2057/ docview/ 1824680215/ D031F9FCD61C4F3CPQ/1? accountid=25704. (Diakses 12 Agustus 2018)

Zhang, Yafei dan Chen, Li. "Exploration of factors leading to successful mediation A regression analysis of reality TV mediation show episodes in China". China, Content analysis, Mediation and litigation, Predictive factors, Reality television. Vol. 1 N0. 28 (16 May 2016), 28. The current issue and full text archive of this journal is available on Emerald Insight at: www.emeraldinsight.com/10444068.htm. (Diakses 12 Agustus 2018) 